\title{
Production of a Novel Ingredient from Buttermilk
}

\author{
M. Corredig*, R. R. Roesch, ${ }^{*}$ and D. G. Dalgleish† \\ ${ }^{*}$ College of Agriculture and Environmental Sciences, \\ Department of Food Science and Technology, University of Georgia, Athens 30602 \\ †Department of Food Science, University of Guelph, Ontario, N1K 2W5 Canada
}

\begin{abstract}
The presence of material derived from the milk fat globule membrane (MFGM) makes buttermilk (the byproduct of butter making) distinct from any other dairy product. Membrane filtration of commercial buttermilk was carried out to obtain isolates rich in MFGM material. The separation of MFGM from the skim milk proteins present in commercial buttermilk was carried out by the addition of sodium citrate followed by microfiltration through a membrane of $0.1-\mu \mathrm{m}$ nominal pore size. The sodium citrate caused the dissociation of casein micelles and allowed permeation of a large proportion of the skim-milk derived proteins through the membrane. This process successfully concentrated MFGM material in the retentate, and demonstrated that membrane filtration can be employed to produce MFGM fractions from commercial buttermilk. The utilization of MFGM isolates from buttermilk is of increasing importance in light of recent studies suggesting the role of phospholipids in many health-related functions: buttermilk is an untapped resource of these functional components.
\end{abstract}

(Key words: buttermilk, dairy ingredient, milk fat globule membrane)

Abbreviation key: MFGM = milk fat globule membrane, $\mathbf{P V D F}=$ polyvinylnilfluoride.

\section{INTRODUCTION}

During the process of butter making, cream undergoes a mechanical treatment, churning, which involves agitation in the presence of air until the fat globules aggregate and disruption of their phospholipid/protein membranes occurs. This membrane material, along with most of the water-soluble material is released into the aqueous phase, called buttermilk. Although the nutritional and functional value of skim milk components is well understood, buttermilk has only recently gained

Received July 29, 2002.

Accepted March 31, 2003.

Corresponding author: M. Corredig; e-mail: corredig@arches. uga.edu. attention as a potential source of functional ingredients. In addition, recent nutritional studies suggest that the consumption of phospholipids may bring health-related benefits. Commercial buttermilk has often been recognized as a good source of phospholipids (Malmsten et al., 1994; Sachedva and Buchheim, 1997). According to the latter authors, the potential phospholipid yield from milk fat globule membrane (MFGM) in buttermilk is about $0.25 \mathrm{mg} / \mathrm{mg}$ of protein.

The production of buttermilk fractions as valueadded ingredients would have a great economic impact; the amount of butter processed in the United States each month averages 50 million $\mathrm{kg}$, with a production of dry buttermilk of about 2 to 2.5 million $\mathrm{kg} / \mathrm{mo}$ (USDA, 2001).

The behavior of whole buttermilk, when used as an ingredient in foods, may be partly attributed to the presence of MFGM, but it is predominantly governed by the presence of skim milk-derived proteins (Corredig and Dalgleish, 1998a). Caseins and whey proteins constitute a large percentage of the total protein in buttermilk. Recently, O'Connell and Fox (2000) discussed the close similarities in physicochemical properties between milk and buttermilk: skim milk and skim buttermilk have comparable total and $\mathrm{pH} 4$.6-soluble proteins and similar size and $\zeta$-potential of casein micelles. Similar research has been carried out on membrane filtration of buttermilk, and the use of buttermilk retentates as ingredients in dairy products (Ramachandra Rao et al., 1995; Mistry et al., 1996; Trachoo and Mistry, 1998). These results suggest that most of the functionality of buttermilk retentates is still to be attributed to the caseins present in high ratio compared with the other proteins and MFGM material.

During laboratory isolation of native MFGM from cream, caseins and serum proteins are removed from the MFGM isolates by repeated washings of the fat globules with appropriate buffers before the cream is churned (Mather, 2000; Ye et al., 2002). This is not applicable to isolation of MFGM from commercial buttermilk, and very little attention has so far been dedicated to the production of MFGM fractions from industrial sources such as commercial buttermilk. The development of a selective isolation procedure of MFGM from 
buttermilk would lead the way to the commercialization of a novel ingredient with unique functional properties.

The production of different buttermilk fractions by adsorption on various biosilicates has recently been reported (Fryksdale and Jiménez-Flores, 2000, 2001). Biosilicates show a higher affinity for phospholipids than neutral lipids. More research needs to be done to optimize the fractionation technologies and to obtain isolated MFGM with small amounts of contaminant proteins; indeed, the isolation of MFGM and the recovery of phospholipids from commercial buttermilk will be possible only if caseins, whey proteins, lactose, and minerals are selectively removed.

Membrane filtration has been employed for bacterial removal in milk (Huffman and Harper, 1999), but it has also been used in casein enrichment, to modify the $\alpha_{\mathrm{s}} / \beta$-casein ratio of milk and for lactose separation in whey protein isolation (Mistry and Maubois, 1993). The difficulty of separation of MFGM from casein micelles by microfiltration of buttermilk has been described by Sachedva and Buchheim (1997). Because of the comparable size of those components, these authors proposed the removal of caseins from reconstituted buttermilk by precipitation of the caseins and subsequent filtration of the buttermilk serum phase, rich in phospholipids. By microfiltration of this buttermilk whey with $0.2-\mu \mathrm{m}$ membranes, the authors reported a recovery of $67 \%$ of the total phospholipids, but the yields varied depending on coagulation conditions. The final buttermilk extract obtained contained about 1.5\% phospholipids and 9\% protein on a dry basis (Sachedva and Buchheim, 1997).

The work presented in this paper describes a study on the isolation of MFGM fractions of commercial buttermilk by membrane filtration. It is demonstrated that, by microfiltration of buttermilk in the presence of agents that dissociate casein micelles, it is possible to obtain a concentrate with a high ratio of membrane material to skim milk-derived proteins.

\section{MATERIALS AND METHODS}

\section{Microfiltration Experiments}

Buttermilk powder was purchased from Dairy Farmers of America (Kansas City, MO). Before drying, the buttermilk had been pasteurized at $76^{\circ} \mathrm{C}$ for $30 \mathrm{~s}$ (according to manufacturer's information). However, it is not known what heat treatment the cream had undergone before the butter-making process; this is discussed below. Reconstituted buttermilk powder $(8 \%$, wt/vol, in deionized water) was separated by membrane filtration using a pilot-scale batch filtration system (NIRO filtration, Hudson, WI). The system was equipped with stackable membranes of various nominal pore size diameter polyvinylnilfluoride (PVDF) 250,000 and 500,000 Da cutoff (Synder Filtration, CA) and Supor 100, 0.1-mm hydrophilic polyethersulfone (Pall Gelman, Ann Arbor, MI). Volumes between 8 and $16 \mathrm{~L}$ of buttermilk were used in each experiment. Most experiments of ultrafiltration and microfiltration were carried out at $50^{\circ} \mathrm{C}$, but some preliminary work was also carried out at $10^{\circ} \mathrm{C}$ with membranes of 250,000 and 500,000 Da. The buttermilk retentate was circulated through the system by a 2-HP centrifugal feed pump (Hydracell Wanner Engineering Inc., Minneapolis, MN) until reaching the desired final concentration, and the temperature was maintained by a shell and tube heat-exchange system maintaining the temperature with a circulating water bath (Neslab HTC 1200 Newington, NH). Pressure was controlled by valves on inlet and outlet permeate ports, and runs were carried out at a retentate pressure of 1.2 MPa. Membranes were cleaned using a cycle of $0.29 \%$ nitric acid, and after rinsing, $0.029 \%$ detergent (Ultrasil II, Klenzade Ecolab Inc., St. Paul, MN). Membranes were considered clean when the water flux recovered its original value, and they were stored in a solution of $0.28 \%$ sodium bisulfate.

The effect of sodium citrate on the separation was also evaluated by adding sodium citrate at a ratio of 1:4 (wt/wt, total buttermilk solids) to reconstituted buttermilk. After the addition of citrate, the buttermilk was stored overnight in a cold room $\left(6^{\circ} \mathrm{C}\right)$ before filtration.

Diafiltration was conducted at $50^{\circ} \mathrm{C}$ after the concentration steps by adding a volume of deionized water corresponding to the permeate volume collected, unless otherwise indicated. Multiple diafiltration steps were carried out as indicated in the results. Retentate and permeates were collected, analyzed for protein concentration and freeze-dried.

\section{Characterization of the Isolates}

The isolates were characterized for composition with a carbon, hydrogen, and nitrogen analyzer (PE 240C Perkin Elmer, Boston, MA, at the University of Georgia Chemical Analysis Laboratories), after microwave digestion in acidic conditions. The lipid content was determined by Sohxlet analysis. The effectiveness of filtration was determined by analyzing the protein composition of permeates and retentates by SDS-PAGE using precast gels (Bio-Rad, Hercules, CA) with 4 to $20 \%$ gradient. Unless otherwise indicated, fresh retentates and permeates were analyzed by dissolving 1 volume of sample in 2 volumes of sample buffer containing 60 $\mathrm{m} M$ Tris- $\mathrm{HCl}, \mathrm{pH} 6.8,25 \%$ glycerol, $2 \%$ SDS, $5 \% 2$ mercaptoethanol, and $0.0125 \%$ bromophenol blue as suggested by the manufacturer (Bio-Rad). Freeze-dried samples were dissolved directly in sample buffer, to 
the concentrations indicated in the figure legends. The mixture of molecular weight standards (Kaleidoscope standards, Bio-Rad) contained myosin, $\beta$-galactosidase, bovine serum albumin, carbonic anhydrase, soybean trypsin inhibitor, lysozyme, and aprotinin. Scanning densitometry of SDS-PAGE gels and image analysis (Bio-Rad Molecular Analyst) of the protein bands were performed to determine differences between permeates and the extent of concentration of the MFGM fractions obtained by filtration.

To estimate the composition of the polar lipid fraction present in the isolates, freeze-dried fractions $(10 \mathrm{mg})$ were twice extracted with chloroform-methanol (2:1 ratio). The extracts were dried under nitrogen flux and dissolved in $0.5 \mathrm{ml}$ of the mobile phase, which consisted of $58 \%$ isopropanol, $40 \%$ hexane, and $2 \%$ water. Samples were injected on to a silica column (Spherisorb 80, Alltech Associates, IL). The solvent gradient was obtained with a Shimatzu HPLC equipment (Shimatzu, MA) as described by Letter (1992). Phospholipids were detected with an evaporative light-scattering detector (Polymer Laboratories, Amherst, MA). The phospholipid elution times were determined by injecting phospholipid standards (phosphatidyl choline, phosphatidyl ethanolamine, sphingomyelin) purchased from Sigma (St. Louis, MO).

\section{RESULTS}

Ultrafiltration of resuspended buttermilk powder was carried out with PVDF membranes with molecular weight cutoffs of 250,000 and 500,000. These experiments were performed at two different operating temperatures, 10 and $50^{\circ} \mathrm{C}$ to test possible differences in permeation of the proteins, because of the reported temperature dependence of the association behavior of proteins in casein micelles (Rollema, 1992). Varying degrees of micellar dissociation can be caused by changes in $\mathrm{pH}$ and temperature of milk (Dalgleish and Law, 1988; Anema and Klostermeyer, 1997).

Figure 1 illustrates the protein composition of the permeate fractions after filtration with PVDF membranes with a 500,000 MW cutoff. Electrophoretic migration of the protein present in the permeate revealed the presence of whey proteins in experiments conducted at 10 and $50^{\circ} \mathrm{C}$. The electrophoretic pattern of the original buttermilk contains major bands from the whey proteins $\alpha$-lactalbumin and $\beta$-lactoglobulin, and from the caseins, together with bands from the membranederived proteins xanthine oxidase and butyrophilin (see for example, Figure 2, lane 5). During filtration at $50^{\circ} \mathrm{C}$ only $\alpha$-lactalbumin and $\beta$-lactoglobulin were found in the permeate, but when filtration was carried out at $10^{\circ} \mathrm{C}$, small amounts of $\beta$-casein were also found. The

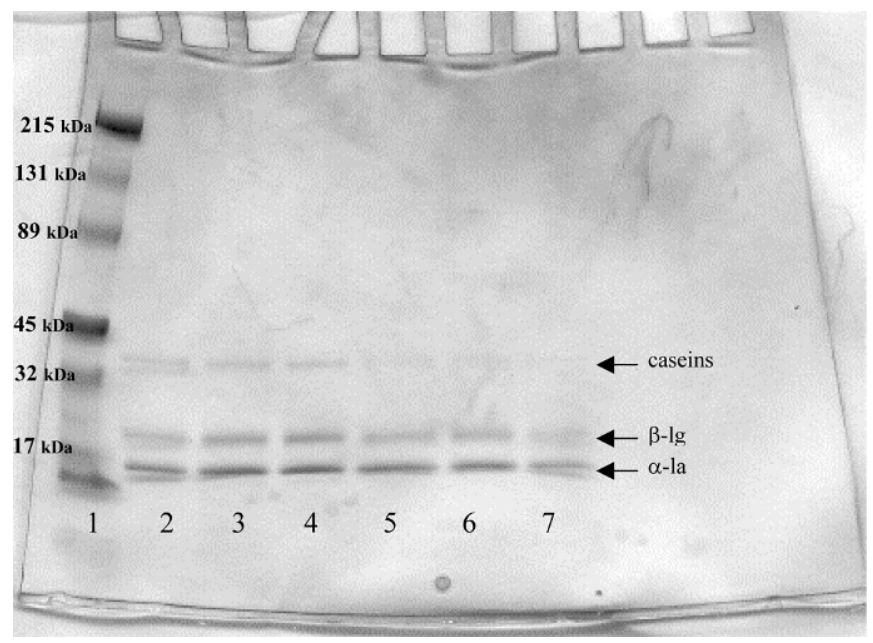

Figure 1. SDS-PAGE of permeates after filtration of buttermilk with polyvinylnilfluoride membranes $\left(500,000\right.$ cutoff) at $10^{\circ} \mathrm{C}$ (lanes 2 to 4 ) and $50^{\circ} \mathrm{C}$ (lanes 5 to 7 ). Lane 1: molecular weight standard. Lanes 2, 5: permeate after $2 \times$ concentration; lanes 3, 6: permeates after diafiltration; lanes 4, 7: permeates after two diafiltration steps.

filtration at low temperature did not seem to be advantageous because, in spite of the permeation of some $\beta$ casein, most casein remained in the retentate, and the flow rates were much lower than those of the filtration carried out at $50^{\circ} \mathrm{C}$. During ultrafiltration with PVDF 250,000 and 500,000, most skim milk-derived proteins

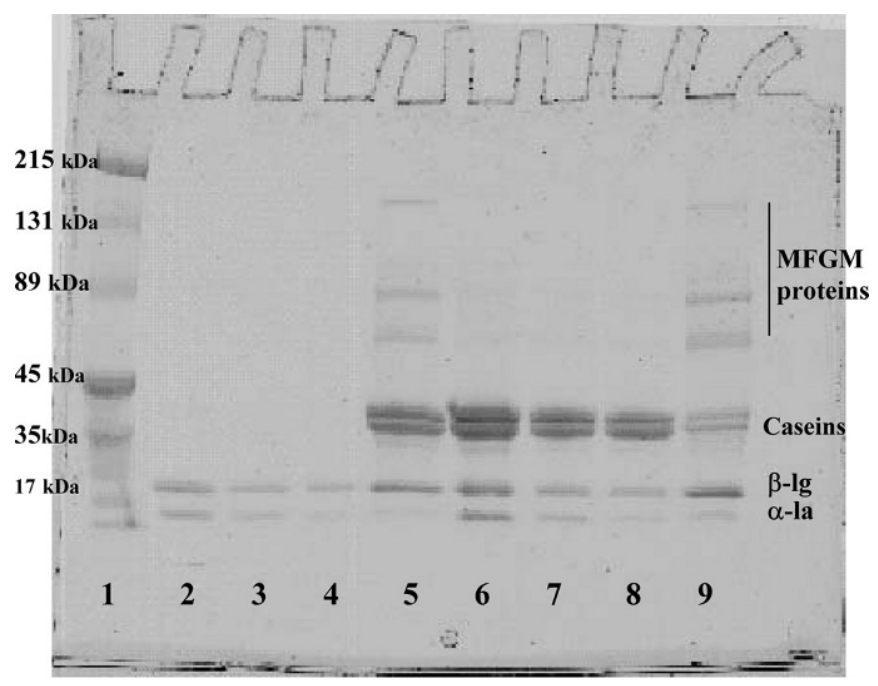

Figure 2. SDS-PAGE of buttermilk fractions after membrane filtration using Supor (Pall Gelman, Ann Arbor, MI) $0.1 \mu \mathrm{m}$ at $50^{\circ} \mathrm{C}$. Lane 1: Molecular weight standards. Lanes 2 to 5 , buttermilk without addition of sodium citrate; Lanes 6 to 9 , buttermilk with added sodium citrate. Lanes 5, 9: final concentrates; lanes 2, 6: permeates $(2 \times$ concentration); lanes 3, 7: permeates after 1 diafiltration step; lanes 4, 8: permeates after two diafiltration steps. Samples for analysis were diluted with 2 volumes of sample buffer. 
present in commercial buttermilk were concentrated in the final retentate with the MFGM material. The ratio of caseins and whey proteins to MFGM material, measured by scanning densitometry, did not change significantly over the steps of filtration. As shown in Figure 1 , only whey proteins could pass through the membrane; however, the filtration was inefficient and whey protein was still found in the retentate fraction after $2 \times$ concentration and diafiltration.

A different approach was then taken in an attempt to separate the caseins from the MFGM fraction. Membrane filtration of commercial buttermilk was carried out on larger nominal pore size membranes (hydrophilic polysulfone membranes-SUPOR $0.1 \mu \mathrm{m}$ ). It has been shown that whey proteins can be effectively separated from micellar caseins using microfiltration membranes (Maubois, 1991; Brandsma and Rizvi, 1999). Filtration methods have been widely used for production of native phosphocaseinate (Brulé et al., 1979; Sachdeva and Buchheim, 1997). Electrophoretic analysis of permeates of buttermilk after filtration through $0.1-\mu \mathrm{m}$ membranes showed fractions similar in composition to those of filtered skim milk, with $\beta$-lactoglobulin and $\alpha$-lactalbumin present (Figure 2, lanes 2 to 4 ). Figure 2 also demonstrates that when sodium citrate was added to buttermilk, the caseins also passed through a $0.1-\mu \mathrm{m}$ SUPOR membrane (Figure 2, lanes 6 to 8).

It has been reported that the dissociation of casein micelles and the formation of soluble caseins can be induced by addition of chaotropic salts or by acidification or chelation of calcium (Holt et al., 1986). Corredig and Dalgleish (1998b) demonstrated that when $2 \%$ sodium citrate was added to buttermilk, micellar dissociation occurred, and isolated MFGM material could be obtained by high-speed centrifugation. During microfiltration of buttermilk with added sodium citrate, it was possible to produce fractions containing a larger ratio of MFGM protein than those prepared by microfiltration with no citrate (compare lanes 5 and 9 in Figure 2 ). Figure 2 illustrates the protein composition of the retentates and permeates after concentration and two subsequent diafiltration steps. No changes occurred in the ratio of proteins present in the permeate samples after two diafiltration steps; however, it appeared that longer diafiltration steps removed greater amounts of protein from the retentate.

Figure 3 shows the composition of retentates and permeates resulting from the filtration of buttermilk with and without added citrate. Profound differences were shown in the ratio of proteins in the permeate when sodium citrate was added. As shown in Figure 3, no differences in the ratio of proteins to MFGM material were shown between the original buttermilk and the retentates from buttermilk to which no citrate was

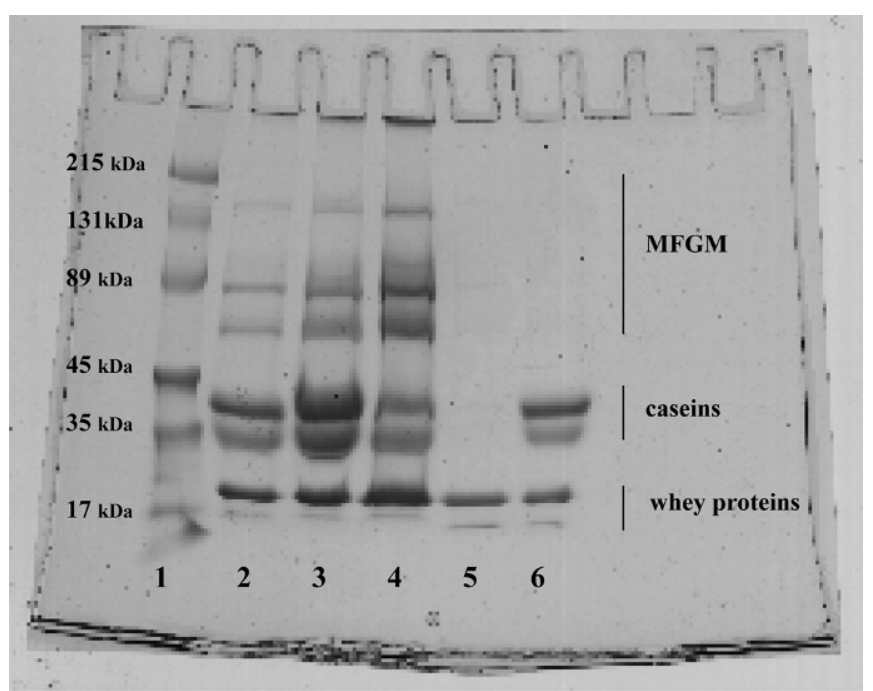

Figure 3. SDS-PAGE of samples prepared by microfiltration of buttermilk through a $0.1-\mu \mathrm{m}$ membrane. Lane 1: Molecular weight standard. Lane 2: buttermilk; lane 3: final concentrate in absence of citrate; lane 4: final concentrate with sodium citrate $(150 \mu \mathrm{g}$ of freezedried sample loaded); lane 5: permeate from buttermilk in the absence of citrate; lane 6: permeate from buttermilk with added citrate (300 $\mu \mathrm{g}$ of freeze-dried sample loaded).

added (Figure 3, lanes 2 and 3): the high molecular weight material migrating in the SDS-PAGE gel (i.e., the protein derived from the MFGM) concentrated along with the caseins during microfiltration. When we filtered buttermilk in the presence of sodium citrate, a fraction enriched in MFGM was obtained, as can be seen by the relative faintness of the casein bands in the lane 4 of figure 3 . This is also demonstrated by the comparison of lanes 5 and 9 in Figure 2.

The permeate fractions shown in Figure 3 both contained considerable amounts of $\beta$-lactoglobulin, but only when buttermilk was treated with citrate were caseins present in the permeates. It was noted that large amounts of $\beta$-lactoglobulin (and to a lesser extent, $\alpha$-lactalbumin) were present in the final retentates after microfiltration, even in the presence of added citrate. This suggests that there are complexes of whey proteins present that are large enough to be retained by the membrane. These complexes may be heat-induced polymers of whey proteins themselves, or may be complexes between whey protein and $\kappa$-CN caused by heating (McSwiney et al., 1994; Oldfield et al., 2000) or may result from the interaction of whey proteins with other components of MFGM (Corredig and Dalgleish, 1996; Dalgleish et al., 1997). Before traditional butter making, the cream is usually given a high enough heat treatment to render it sterile, and it is this heat treatment that is probably responsible for the behavior of the whey proteins that were found in the membrane 
material. Unfortunately, we do not know what the temperature of this heat treatment was for our particular sample of buttermilk. It is to be expected that this may be a variable between batches. This is especially true if the buttermilk from the "plastic cream" process of manufacturing butter oil is used as a feedstock for the microfiltration process; such a material may have received a lower heat treatment, and will also contain considerably less total protein that the traditional buttermilk.

The addition of sodium citrate increased the $\mathrm{pH}$ of buttermilk from the original value of 6.8 to 7.5 , and there was a further increase of 0.2 units during the microfiltration/diafiltration process. It was determined by image densitometry that after concentration and two diafiltration steps, even though the amounts of caseins were reduced compared with the other proteins present in the retentate, they still represented $30 \%$ of the total proteins. In an attempt to optimize the isolation process, multiple diafiltration steps were carried out to determine whether permeation of skim milk-derived proteins could be further improved. Figure 4 illustrates the protein composition of permeates and retentates resulting from repeated concentration/diafiltration steps. Each diafiltration step (repeated additions of deionized water and concentration) resulted in further permeation of caseins through the $0.1-\mu \mathrm{m}$ filter (Figure $4 \mathrm{~A}$ ) with a corresponding increase in the ratio of MFGM isolate present in the retentate. In addition to MFGM protein, both whey proteins $\beta$-lactoglobulin and $\alpha$-lactalbumin concentrated in the retentate. Electrophoretic analysis of the various permeates demonstrated that whey protein permeated only in the initial stages of filtration, and after the first diafiltration step very little whey protein was released into the permeate. This suggests that the whey proteins are probably not bound to caseins, but are self-aggregated or bound to the membrane material.

Two independent runs were carried out with extensive concentration and dialysis (Figure 4) and after freeze-drying yields of 15 and $18 \%$ of retentate (wt/ wt of dried retentate/original buttermilk powder) were obtained. These yield values showed the potential of such process for producing MFGM isolates, and could be further improved depending on the level of casein "contamination" that could be tolerated in the MFGM isolate. The yields are low because the buttermilk originally contains, as well as the MFGM and the caseins, amounts of lactose and of salts that are lost during the concentration and diafiltration processes.

Figure 5 depicts the protein composition of the two batches of MFGM isolates prepared, as analyzed by SDS-PAGE. The isolates contained about $60 \%$ (wt/wt) protein and $35 \%$ (wt/wt) lipid. Of the protein fraction,

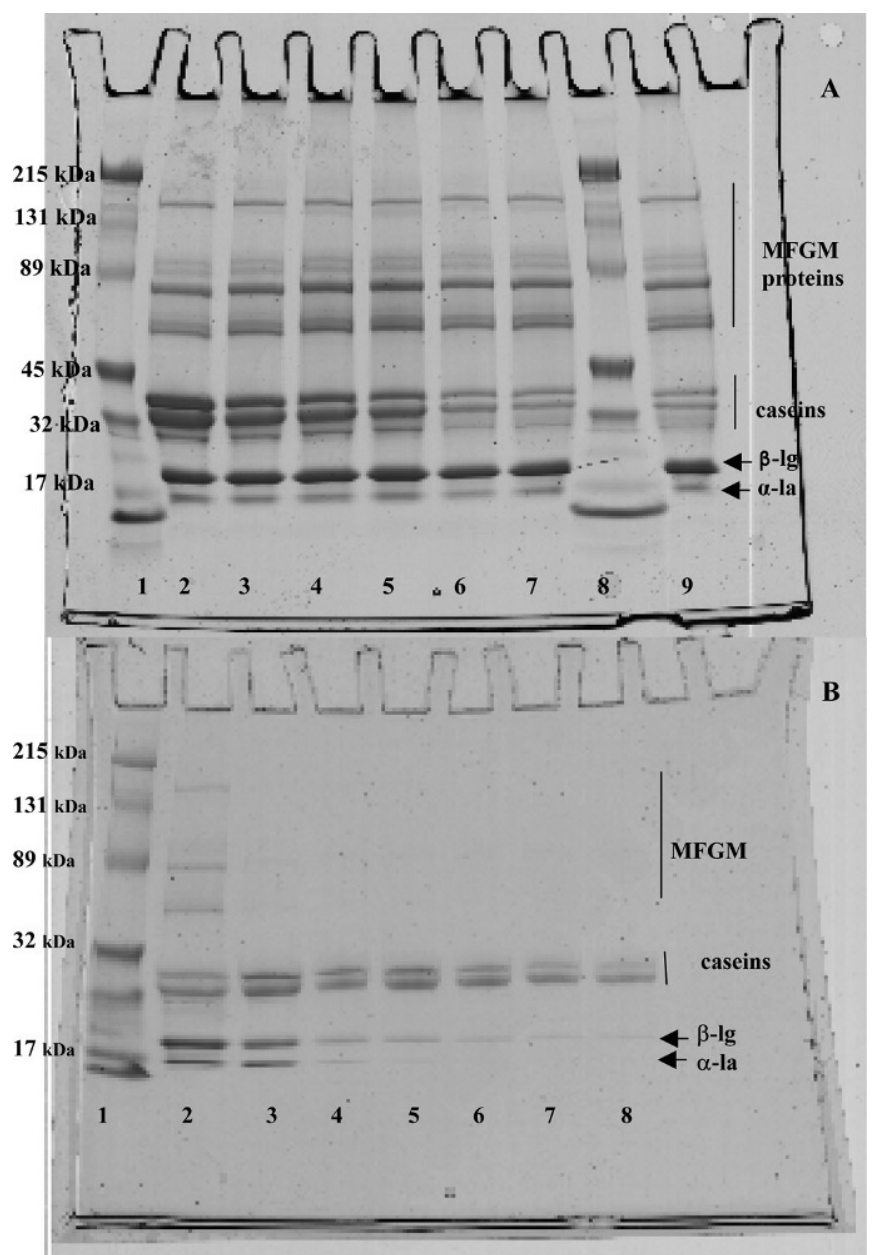

Figure 4. SDS-PAGE analysis of retentate (A) and permeate (B) samples at different stages of filtration of $10 \mathrm{~L}$ of $4 \%$ buttermilk $1 \%$ citrate, at $50^{\circ} \mathrm{C}$. Lanes $1,8(\mathrm{~A})$ and 1 (B): molecular weight standards; A: Lane 2: $4 \times$ concentrate; lane 3: retentate after 1 diafiltration step (addition of 21 of deionized water); lanes 4, 5, and 6: retentate after two, three, and four diafiltration steps, respectively; lanes 7, 9 final concentrate. B: Lane 2, original buttermilk; lane 3: permeate, concentration step; lanes 4 to 7 : permeates at subsequent diafiltration steps; lane 8: final permeate.

the MFGM proteins represented about $70 \%$, the residual caseins $6 \%$ and the whey proteins $24 \%$ of the total selected peak areas as determined by image densitometry analysis.

The lipid fraction was further extracted and analyzed by HPLC, and Figure 6 illustrates the elution of the polar lipids. The extract prepared from MFGM isolates showed an increase in the phospholipid peaks compared to the extract from the original buttermilk powder. The process of filtration of buttermilk after addition of sodium citrate seemed to increase the amount of phospholipids present in the MFGM isolate. A large peak of unbound material was also present in both samples, indicating that neutral lipids were still present in large 


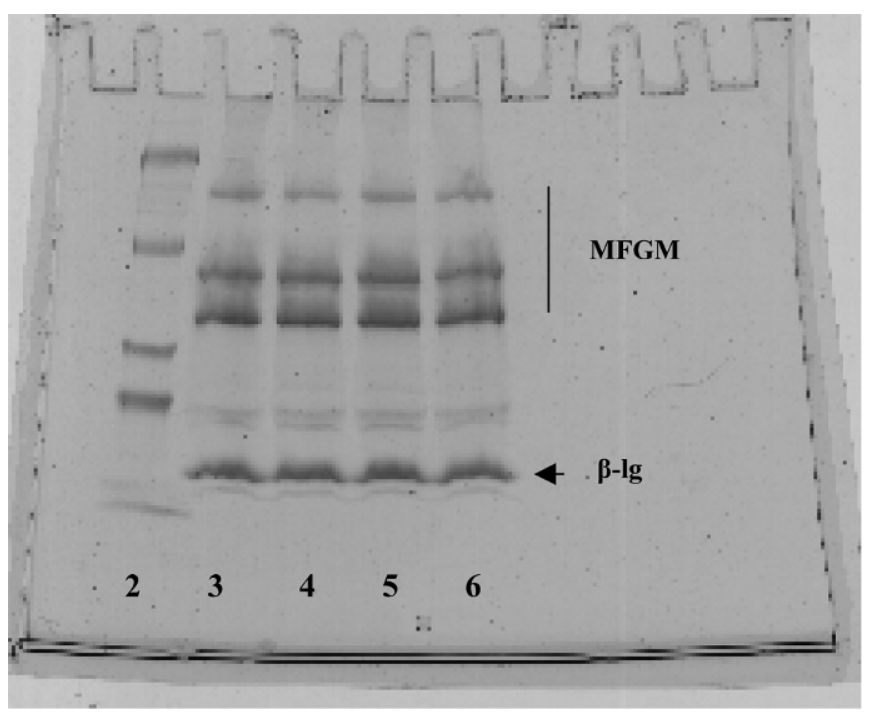

Figure 5. SDS-PAGE of freeze-dried milk fat globule membrane (MFGM) isolate. Lane 2: molecular weight standard, lanes 3, 4: MFGM batch 1; lanes 5, 6 MFGM batch 2 (150 mg of freeze-dried MFGM loaded).
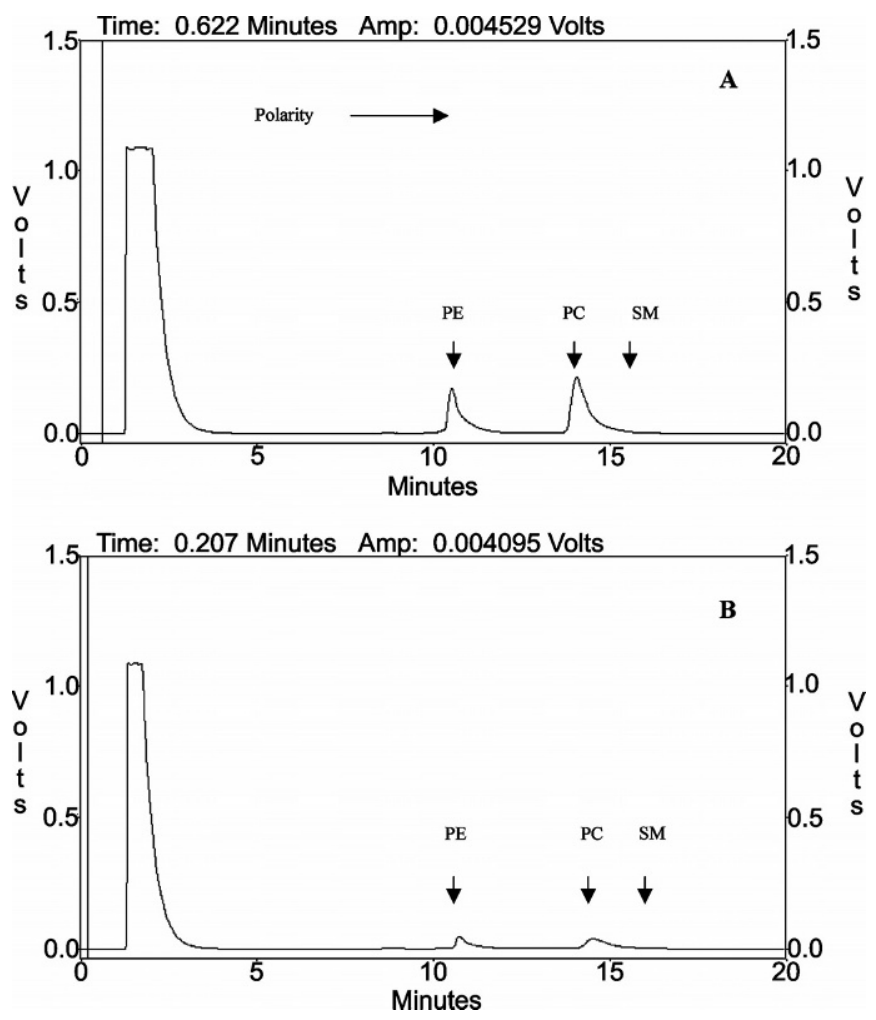

Figure 6. Elution chromatogram of the lipid fraction injected on silica column (Spherisorb 80, Alltech, Nicholasville, KY) A. Buttermilk retentate with citrate added (milk fat globule membrane isolate); B. Buttermilk retentate, no citrate added. The elution volume of standard samples is indicated by arrows, from left to right, phosphatidyl ethanolamine (PE), phosphatidyl choline (PC), sphingomyelin (SM). amounts in both samples. This fraction could have derived from the small percentage of residual fat droplets in the original buttermilk, which would be concentrated during microfiltration.

It has been previously reported that sphingomyelin, phosphatidyl choline, and phosphatidyl ethanolamine are the main phospholipids classes present in native MFGM, at 25, 35, and 32\%, respectively (Malmsten et al., 1994; Kennan and Dylewski, 1995; Jensen, 2002). Analysis of buttermilk itself and the retentates showed only two polar lipids to be present in these samples. The two polar lipids eluted were identified as phosphatidyl ethanolamine and phosphatidyl choline by using standards (Figure 6).

In milk, MFGM phospholipids represent only less than $1 \%$ of the total lipids (Christie et al., 1987); however, the isolation of MFGM seemed to concentrate these high-value components as shown in Figure 6A. Phospholipids have gained popularity as ingredients in the past few years, and the MFGM isolates prepared by microfiltration could find employment in the fast developing market of physiologically functional foods. The partitioning of the phospholipid fraction could perhaps be further controlled by performing the microfiltration at lower temperatures.

\section{CONCLUSIONS}

The addition of sodium citrate to buttermilk was necessary to disrupt micellar caseins and allow permeation of the skim milk-derived proteins through a $0.1-\mu \mathrm{m}$ filter. The process resulted in a protein isolate containing a high ratio of MFGM material. Considerable quantities of whey proteins (especially $\beta$-lactoglobulin) were present with the MFGM material, as a consequence of the processing history of the commercial product used. We concluded that microfiltration has potential as an industrial scale means of isolating MFGM fractions from buttermilk. To date, this is the only successful method in extracting MFGM with very little skim milk contaminants from a commercial buttermilk source. More research needs to be carried out to determine the differences in products by using varying sources of buttermilk with different processing history, and the possible utilization of the dissociated casein fractions present in the permeate. More understanding of the effect occurring to the MFGM during processing of buttermilk powders and the cream they derive from, would further improve the quality of the ingredient that could be prepared by microfiltration.

\section{ACKNOWLEDGMENTS}

This work was funded in part by Danone Vitapole, le Plessis-Robinson, France. 


\section{REFERENCES}

Anema, S. G., and H. Klostermeyer. 1997. Heat-induced pH-dependent dissociation of casein micelles on heating reconstituted skim milk at temperatures below $100^{\circ} \mathrm{C}$. J. Agric. Food Chem. 45:1108-1115.

Brule, G., J. Fauquant, and J. L. Maubois. 1979. Preparation of "native" phosphocaseinate by combining membrane ultrafiltration and ultracentrifugation skim milk. J. Dairy Sci. 62:869-875.

Christie, W. W., R. C. Noble, and G. Davies. 1987. Phospholipids in milk and dairy products. J. Soc. Dairy Technol. 40:10-12.

Corredig, M., and D. G. Dalgleish. 1996. Effect of different heat treatments on the strong binding interactions between whey proteins and milk fat globule in whole milk. J. Dairy Res. 63:441-449.

Corredig, M., and D. G. Dalgleish. 1998a. Buttermilk properties in emulsions with soybean oil as affected by fat globule membranederived proteins. J. Food Sci. 63:476-480.

Corredig, M., and D. G. Dalgleish. 1998b. Characterization of the interface of an oil-in-water emulsion stabilized by milk fat globule membrane material. J. Dairy Res. 65:465-477.

Dalgleish, D. G., and A. J. R. Law. 1989. pH-Induced dissociation of bovine casein micelles. II. Mineral solubilization and its relation to casein release. J. Dairy Res. 56:727-735.

Dalgleish, D. G., L. van Mourik, and M. Corredig. 1997. Heat-induced interactions of whey proteins and casein micelles with different concentrations of $\alpha$-lactalbumin and $\beta$-lactoglobulin. J. Agric. Food Chem. 45:4806-4813.

Fryksdale, B. G., and R. Jimenez-Flores. 2000. Modification of buttermilk functionality with biosilicates. J. Dairy Sci. 83(Suppl. 1):97. (Abstr.)

Fryksdale, B. G., and R. Jimenez-Flores. 2001. Modification of buttermilk functionality with a biosilicate adsorption process. Page 209 in IFT Annual Meeting Technical Program Abstracts.

Holt, C., D. T. Davies, and A. J. R. Law. 1986. Effects of colloidal calcium phosphate content and free calcium ion concentration in the milk serum on the dissociation of bovine casein micelles. J. Dairy Res. 53:557-572.

Huffman, L. M., and W. J. Harper. 1999. Maximizing the value of milk through separation technologies. J. Dairy Sci. 82:2238-2244.

Jensen, R. G. 2002. The composition of bovine milk lipids: January 1995 to December 2000. J. Dairy Sci. 85:295-350.

Keenan, T. W., and D. P. Dylewski. 1995. Intracellular origin of milk lipid globules and the nature and structure of the milk lipid globule membrane. Pages 89-130 in Advanced Dairy Chemistry. Volume 2: Lipids. P. F. Fox, ed. Chapman \& Hall, London.
Letter, W. S. 1992. A rapid method for phospholipids class separation by HPLC using an evaporative light-scattering detector. J. Liquid Chromatogr. 15:253-266.

Malmsten, M., B. Bergenståhl, L. Nyberg, and G. Odam. 1994. Spingomyelin from milk - characterization of liquid crystalline, liposome and emulsion properties. JAOCS 71:1021-1026.

Maubois, J. L. 1991. New applications of membrane technology in the dairy industry. Aust. J. Dairy Technol. 46:91-95.

Mather, I. H. 2000. A review and proposed nomenclature for major proteins of the milk-fat globule membrane. J. Dairy Sci. 83:203-247.

McSwiney, H., H. Singh, and O. H. Campanella. 1994. Thermal aggregation and gelation of bovine $\beta$-lactoglobulin. Food Hydrocoll. $8: 441-453$.

Oldfield, D. J., H. Singh, M. W. Taylor, and K. N. Pearce. 2000. Heatinduced interactions of $\beta$-lactoglobulin and $\alpha$-lactabumin with the casein micelle in pH-adjusted skim milk. Int. Dairy J. 10:509-518.

Mistry, V. V., and J. L. Mabouis. 1993. Application of membrane separation technology to cheese production. Pages 493-522 in Cheese: Chemistry, Physics, and Microbiology. General Aspects. Vol. 1. P. F. Fox, ed. Elsevier Applied Science, London.

Mistry, V. V., L. E. Metzger, and J. L. Maubois, 1996. Use of ultrafiltered sweet buttermilk in the manufacture of reduced fat cheddar cheese. J. Dairy Sci. 79:1137-1145.

O'Connell, J. E., and P. F. Fox. 2000. Heat stability of buttermilk. J. Dairy Sci. 83:1728-1732.

Ramachandra Rao, H. G., M. J. Lewis, and A. S. Grandison. 1995. Effect of $\mathrm{pH}$ on flux during ultrafiltration of sweet whey and buttermilk. J. Dairy Res. 62:441-449.

Rollema, H. S. 1992. Casein association and micelle formation. Pages 111-140 in Advanced Dairy Chemistry. Vol. 1. Proteins. P. F. Fox, ed. Blackie Academic Professional, Chapman and Hall, London.

Sachdeva, S., and W. Buchheim. 1997. Recovery of phospholipids from buttermilk using membrane processing. Kieler Milchwirtschaftliche Forschungsberichte 49:47-68.

Sachdeva, S., and W. Buchheim. 1997. Separation of native casein and whey proteins during crossflow microfiltration of skim milk. Aust. J. Dairy Technol. 52:92-97.

Trachoo, N., and V. V. Mistry. 1998. Application of ultrafiltered sweet buttermilk and sweet buttermilk powder in the manufacture of non fat and low fat yogurts. J. Dairy Sci. 81:3163-3171.

USDA 2001. National Agricultural Statistics Service Bulletin.

Ye, A., H. Singh, M. W. Taylor, and S. Anema. 2002. Characterization of protein components of natural and heat-treated milk fat globule membranes. Int. Dairy J. 12:393-402. 